\title{
Gap analysis of land availability and land needs to identify potential development of agricultural lands in Santan watersheds, East Kalimantan, Indonesia
}

\author{
AKHMAD SOPIAN ${ }^{1,2, \boldsymbol{v}}$, SIGIT HARDWINARTO ${ }^{1}$, MARLON IVANHOE AIPASSA ${ }^{1}$, SUMARYONO $^{1}$ \\ ${ }^{1}$ Program of Forestry Science, Graduate Program, Faculty of Forestry, Universitas Mulawarman. Jl. Gunung Kelua, Campus Unmul, Samarinda. \\ ${ }^{2}$ Program of Agrotechnology, Universita Widya Gama. Jl. K.H Wahid Hasyim, Sempaja, Samarinda 75124, East Kalimantan, Indonesia. \\ Tel./fax.: +62-541-736572, `email: sopian@uwgm.ac.id
}

Manuscript received: 5 December 2018. Revision accepted: 23 March 2019.

\begin{abstract}
Sopian A, Hardwinarto S, Aipassa MI, Sumaryono. 2019. Gap analysis of land availability and land needs to identify potential development of agricultural lands in Santan watersheds, East Kalimantan, Indonesia. Biodiversitas 20: 1097-1105. Pressures caused by high population growth in various places increase the needs for lands. The aims of this research are to determine the availability and needs of agricultural lands in Santan 1 and Santan 2 watersheds, East Kalimantan, Indonesia as well as to classify land capability which are key aspects in managing land resources. Land availability was determined based on the local actual total production of all commodities, such as agriculture, plantation, and livestock at the sub-district level. Land needs were determined based on the land area required for decent life needs per resident. While land capability was determined using weighting analysis of the limiting factors. Results of this study show that land availability on Santan 1 and Santan 2 watersheds is inadequate to fulfill the needs of inhabitants for agricultural lands. There are 19,053 hectares of lands currently available for agriculture, while there are 56,969 hectares of lands required for agriculture, implying a deficit of 37,916 ha of land. Analysis on land capability shows that lands with eutropepts and tropudults soil with total extent of 16,650,9 hectares are potential to be developed for dryland agriculture, such as seasonal crops, while tropohemist soil is suitable for farmland development, such as lowland rice. The spatial plans in Santan 1 and Santan 2 watersheds do not have adequate lands with agricultural capability since the cultivation areas are situated in VI and VII class with limiting factor of slope and erosion. We find there is undeveloped land in the form of bushes with an extent of 12,989,3 hectares in Santan 1 watershed and 7,055.54 hectares in Santan 2 watershed as potential lands to be developed for dryland agriculture. The results of this study suggest that when establishing neighborhood and hamlet should refer to soil characteristics with certain land capability and cultivation activities not to be done on lands with slopes of $>15 \%$.
\end{abstract}

Keywords: Agricultural land, availability, potential, watershed

\section{INTRODUCTION}

The increasing number of human population affects forest areas due to the needs of lands to fulfill foods and shelters. Conversion of forest areas into agricultural lands, human settlements, and other land uses causes negative effects to land and water resources (Fauzi et al. 2018). Watershed is a landscape level management that regulates hydrological system affected by biophysical factors such as reliefs, topography, physiography, climate, soil, water and vegetation. However, the use of lands is also related closely to human activities which may disturb the balance of ecosystem. The changes of forest areas into agricultural lands also cause damages in the ecosystems at watershed level as considerable areas in the landscape become incompatible with its capability, affecting its carrying capacity and quality (Sinukaban 2007; Harjianto et al. 2016). Ramadhan et al. (2016) reported that incompatibility in terms of the use of an area could cause landslide problems. Large changes in land uses without taking into account natural resources sustainability and environmental functions would cause land degradation which may trigger erosion, sedimentation, flood, and landslide in watershed ecosystems.

Land capability classification is a systematic assessment to classify land or land's components into several categories based on the characteristics of the potentials and barriers of its prescribed uses, for example, land capability class for paddy rice field or agroforestry crops (Arsyad 2010; Budiharta et al. 2016). Maryati (2013) stated that land capability assessment is a process to evaluate land potentials based on its capability for sustainable use. According to Costa et al. (2019), The gains for land use policy are apparent because land capability maps are fundamental instruments in the management of rural areas, namely to help the mitigation of a major global concern nowadays, which is land degradation.

Numerous methods of collecting and processing data have been applied and developed in order to manage the natural resources in watershed. Rosca et al. (2015) and Bhandari et al. (2014) stated that research to study land capability classification, Geographic Information System (GIS) techniques are commonly used using several environmental indicators such as climate, morphometric, morphology, and pedology. In the context of agriculture, map of uniformity and capability of land use is developed 
to classify uniformity and capability level of a landscape through spatial representation. This method was also used by Mohamed et al. (2016) who find better option which could be applied in various land use policies since the conventional land evaluation methods have limitations in presenting the results in a spatially-explicit way. Rider (2003) reported participatory approach to agricultural research and development is particularly relevant in soil survey. Widiatmaka et al. (2015) Land resources mapping and land evaluation is one tool that can be used to provide the data for establishing local specific inputs in the context of sustainable agricultural planning.

Santan 1 and Santan 2 watersheds are located in East Kalimantan Province, Indonesia encompassing the districts of East Kutai, Kutai Kartanegara, and City of Bontang. According to the data by Watershed Management Office (BPDAS), Ministry of Environment and Forestry in 2012, Santan watersheds has an area of 130,056.46 hectares. Santan 1 and Santan 2 watersheds consist of broad ranges of degradation condition from non-critical lands, potentially critical lands, quite critical and critical lands and put as the second priority in watershed management in Kalimantan (BPDAS 2014). Some areas of both watersheds are within Kutai National Park which is known for its richness in biodiversity. Kutai National Park is the representation of the widest ironwood (Eusideroxylon zwageri) forest in Indonesia, in addition to habitat of plants such as mangrove like Rhizophora sp., Bruguiera sp., Casuarina equisetifolia, Dillenia sp., Shorea sp., Octomeles sumatrana, Dryobalanops sp., and E. zwageri. The national park has also very high animal diversity including primate species such as Pongo satyrus, Hylobates muelleri, Nasalis larvatus, Macaca pascicularis, M. nemestrina and Nycticebus caucang (Sawitri et al. 2011; Bani et al. 2018; Muhlisi and Gunawan. 2016) . However, Kutai National Park is threatened by land encroachment for settlements, agriculture areas, plantations and minings with escalating number of illegal inhabitants since the 2000s era.

Population in Santan watersheds is increasing, from 88,518 in 2010 into 100,461 in 2015. The growing population has an impact on the increasing needs for agricultural land, but is not balanced by the land availability. Wangke (2017) reported the occupation by the local community becomes inevitable because of very high dependant on land and forest products in Kutai National Park (Santan). Based on data from the Ministry of Environment and Forestry in 2016, the extent of production forest that can be converted is 3,660 hectares. This condition cause pressure on land ownership, triggering tenure conflict. The limited agricultural land also generates land clearing that does not meet land capability and forest function.

This research examines the gap between the availability of agricultural lands and the needs for agricultural lands in Santan 1 and Santan 2 watersheds to fulfill the inhabitants' needs. Then we identify land capability across two watersheds which may suitable for agricultural development based on Regulation of Ministry of Environment No. 17 Year 2009 concerning guidelines for determining environmental carrying capacity in spatial planning. Therefore, land suitable for agriculture areas, land that should be protected, and land that can be used for other purposes can be known. This evaluation of land use suitability is needed as a reference for revision of existing spatial planning.

\section{MATERIALS AND METHODS}

This research had been carried out from December 2015 to December 2016, using descriptive case study method by describing an object of study (Figure 1). This research was done in Santan 1 and Santan 2 watersheds that were administratively situated in East Kutai District, Kutai Kertanegara District, and City of Bontang, East Kalimantan Province, Indonesia. Both watersheds, Santan 1 and Santan 2 are separated by river and managed by BPDAS (Central Management of Watersheds) Mahakam, East Kalimantan.

\section{Land availability and land needs}

The calculation of land availability was determined from the total sub-district actual production from all agricultural commodities in an area by summing up the products of all agriculture, plantation and livestock products within the research area based on the regulation of Ministry of Environment (2009) using following formula:

$$
\mathrm{S}_{\mathrm{L}}=\frac{\sum(\mathrm{Pi} \times \mathrm{Hi})}{\mathrm{Hb}} \times \frac{1}{\mathrm{Ptv}_{\mathrm{b}}}
$$

Where;

$\mathrm{S}_{\mathrm{L}} \quad$ : Land availability (ha)

$\mathrm{P}_{\mathrm{i}} \quad$ : The actual production of commodity types

$\mathrm{H}_{\mathrm{i}} \quad$ : Price per unit of every commodity (Rp/unit) in supplier level

$\mathrm{H}_{\mathrm{b}} \quad$ : Price per unit of rice $(\mathrm{Rp} / \mathrm{kg})$ in supplier level

Ptvb : Rice Productivity (kg/ha)

Commodity price data were obtained from the results of field survey, meanwhile, productivity data were gained from the central statistics offices for sub-districts of South Sangatta, Teluk Pandan, Muara Kaman, South Bontang, and Marangkayu.

Meanwhile, land needs were determined based on the regulation of Ministry of Environment (2009) using following formula:

$\mathrm{D}_{\mathrm{L}}=\mathrm{N} \times \mathrm{KHL}_{\mathrm{L}}$

Where;

$\mathrm{D}_{\mathrm{L}} \quad$ : The total of land needs equal to rice (ha)

$\mathrm{N}$ : Number of inhabitants

$\mathrm{KHL}_{\mathrm{L}}$ : Price per unit of every commodity (Rp/unit) in supplier level

Ptvb : Rice Productivity (kg/ha)

The criteria of land carrying capacity status where SL $>$ DL, then the carrying capacity is categorized as surplus, but when SL $<\mathrm{DL}$, then it is categorized as deficit. 

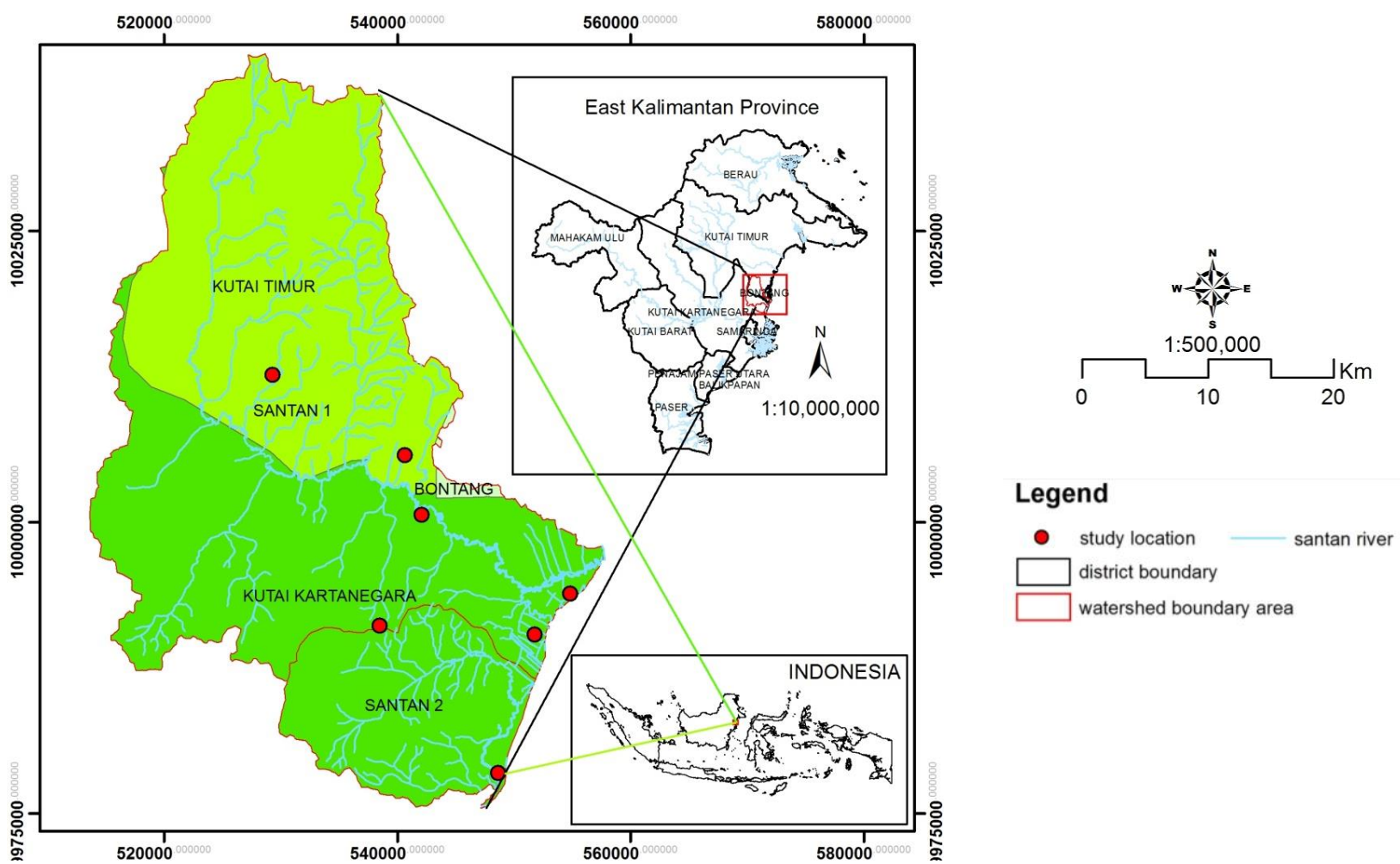

Figure 1. Map of study location in East Kutai District, Kutai Kertanegara District and City of Bontang, East Kalimantan Province, Indonesia

\section{Land capability}

Determination of land capability was initiated from the making of map for land unit. Land unit was used as the basic unit in an analysis. Land capability was mapped by overlaying slope map, soil map, erosion map, and drainage map with scale of $1: 350.000$. The land capability map was then overlaid using land cover maps to develop unit of land. Unit of land is the smallest unit for observation analysis with minimum width of 25 hectares (BAPLAN 2015). The characters of land unit are related to restricting factors and its potential to be developed based on its suitability with land use. Collection on edaphic data (soil characteristics and features) was conducted through survey method and laboratory analysis. Land survey was carried out to find out and match the result of interpretation with the real condition on the field. The land covers were observed during the survey using GPS.

Data of soil depth, land inclination, drainage, erosion risks, rocks and flood or puddle were also collected during the survey. The texture, permeability of soil and its chemical properties, such as $\mathrm{pH}, \mathrm{C}$ organic, N, P, K, KTK, $\mathrm{KB}$, were determined through soil analysis, conducted at soil laboratory in Agricultural Faculty of Mulawarman University. Land capability classification method is based used USDA classification system (Klingebiel and Montgomery 1973; Arsyad 2010). From the survey outcome and laboratory analysis, limiting factor determination was done which consisted of slopes, textures and effective depth, erosion and flood danger level. The coordinate location, altitude, and land cover of the research area are displayed in Table 1.
Table 1. Coordinate location, altitude and land cover in the research area

\begin{tabular}{clcl}
\hline $\begin{array}{c}\text { Study } \\
\text { location }\end{array}$ & Type of soil & $\begin{array}{c}\text { Alt. } \\
\text { (m asl) }\end{array}$ & Land cover description \\
\hline 1 & Tropahemists & 9 & Secondary swamp forest \\
2 & Tropudults & 59 & Mixed dryland agriculture \\
3 & Dystropepts & 71 & Scrub and bushes \\
4 & Eutropept & 15 & Timber plantation \\
5 & Sulfaquents & 36 & Scrub and bushes \\
6 & Hydraquents & 12 & Fishpond \\
7 & Troporthent & 89 & Scrub and bushes \\
\hline
\end{tabular}

The land capability is classified into eight classes, from Class I to Class VIII wherein the risk of damage and the amount of restricting factors are increasing as the level of class increasing. Meanwhile, Classes of I-IV are considered appropriate for agriculture.

\section{RESULTS AND DISCUSSION}

\section{Slope and topography}

Study areas have flat to moderately steep topography. Topography suitable for agricultural cultivation is $20 \%$ and $18 \%$ in Santan 1 watershed and Santan 2 watershed, respectively. These areas have an extent of 25,501.33 hectares in Santan 1 watershed and 4,616.85 hectares in Santan 2 watershed. The remaining topography is not suitable for agriculture, including in Santan 1 watershed 
which: $50 \%$ are sloping and hilly and $30 \%$ are moderately steep, while in Santan 2 watershed of $55 \%$ are sloping and hilly and $27 \%$ are moderately steep. Detailed slope and topography of the studied areas are shown in Table 3.

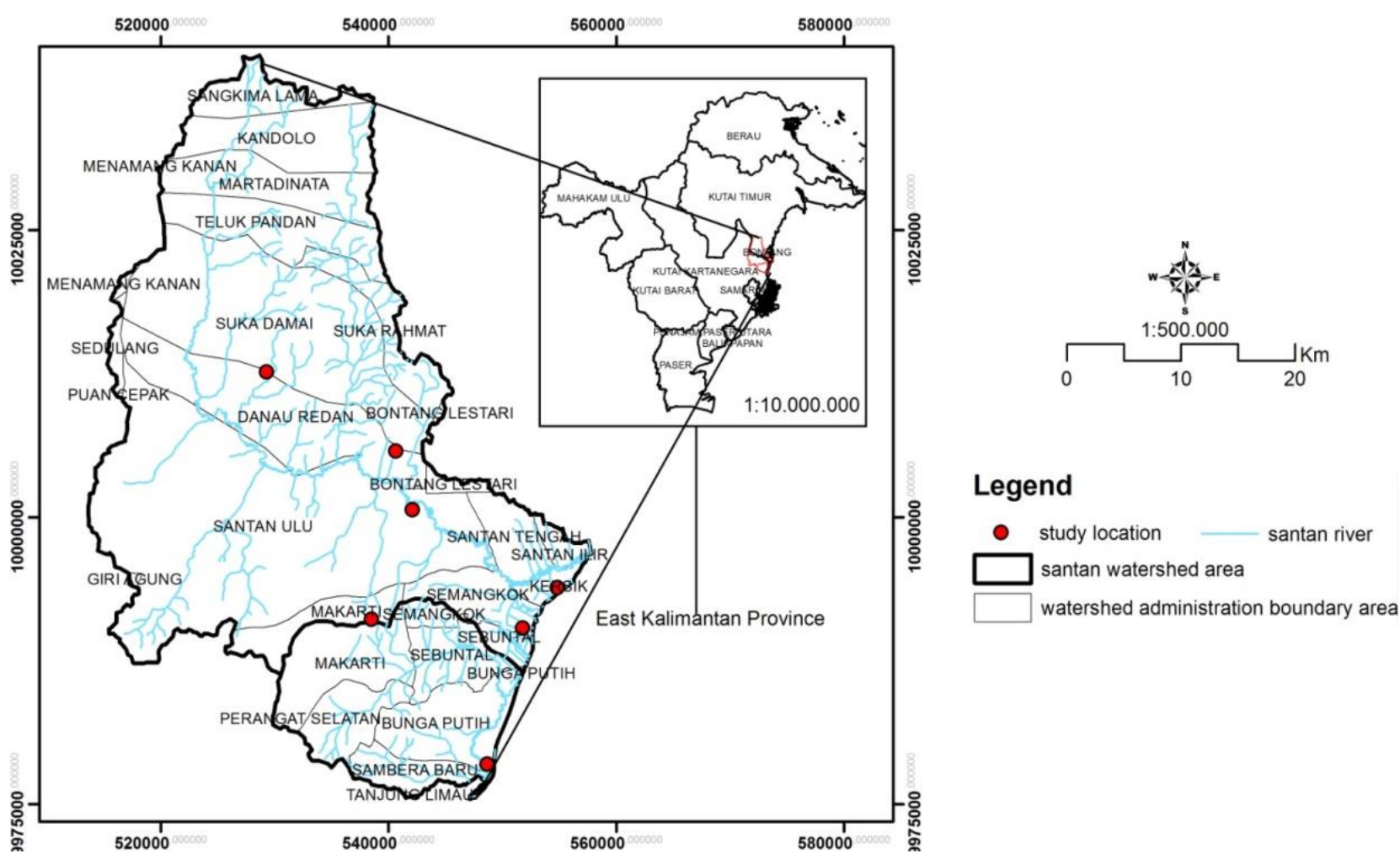

Figure 2. Map of survey location in the research area in East Kalimantan, Indonesia

Table 2. Land capability classification in management unit level

\begin{tabular}{|c|c|c|c|c|c|c|c|c|}
\hline \multirow{2}{*}{ Limiting factor } & \multicolumn{8}{|c|}{ Land capability class } \\
\hline & I & II & III & IV & V & VI & VII & VIII \\
\hline \multicolumn{9}{|l|}{ Soil Texture (t) } \\
\hline Upper Surface $(40 \mathrm{~cm})$ & ah-s & h-ak & h-ak & $(*)$ & $(*)$ & $(*)$ & $(*)$ & $(*)$ \\
\hline Lower Surface & ah-s & h-ak & h-ak & $(*)$ & $(*)$ & $(*)$ & $(*)$ & $(*)$ \\
\hline Slope Surface (\%) & $0-3$ & $3-8$ & $8-15$ & $15-30$ & $(*)$ & $30-45$ & $45-65$ & $>65$ \\
\hline Drainage & $b-a b$ & aj & $\mathrm{j}$ & $\mathrm{sj}$ & $(* *)$ & $(*)$ & $(*)$ & $(*)$ \\
\hline Effective Depth & $>90$ & $>90$ & $90-50$ & $90-25$ & $(*)$ & $<25$ & $(*)$ & $(*)$ \\
\hline Erosion State & $\mathrm{t}$ & $\mathrm{r}$ & $\mathrm{r}$ & $\mathrm{s}$ & $(*)$ & $\mathrm{b}$ & $\mathrm{sb}$ & $(*)$ \\
\hline Stones & $0-15$ & $0-15$ & $0-15$ & $15-50$ & $50-90$ & $(*)$ & $(*)$ & $>90$ \\
\hline Flood & o0 & o1 & $\mathrm{o} 2$ & o3 & o4 & $(*)$ & $(*)$ & $(*)$ \\
\hline
\end{tabular}

Note: $(*)$ : May have distribution of limiting factor properties from lower classes; $\left({ }^{*}\right)$ : Soil surface was always submerged by water

Texture:

ah: pretty smooth,

h: smooth,

s: medium,

$\mathrm{k}$ : rough,

ak: pretty rough
Drainage:

b: good,

ab: pretty good,

aj: pretty bad,

j: bad,

sj: very bad
Erosion:

t: none,

r: light,

s: medium,

b: heavy,

sb: very heavy
Threat of flooding :

o0: never

o1: sometimes

o2: during a month in a year, regularly covered by flood $>24$ hours o3: during 2-5 months in a year, regularly covered by flood $>24$ hours o4: during six months or more, regularly covered by flood $>24$ hours 
Santan 1 watershed is dominated by sloping and hilly to moderately steep topography. Lands with $<15 \%$ of sloping are suitable for agriculture and plantation. On the contrary, lands with $>15 \%$ of sloping are not recommended for dryland food crops because of the risks of erosion and landslide (Hardjowigeno and Widiatmaka 2011; Rachman et al. 2018). The soil type of dystropepts, rendols, troporthen, and tropudults are located on sloping and hilly to moderately steep topography. In Santan 1 watershed, the areas with flat to -moderately sloping topography which are potential for agricultural land consist of eutropepts, and tropohemis soil types. Eutropepts soil is classified as inseptisol while tropudults is classified as ultisol soil. Eutropepts soil types are suitable for fruit, vegetable, rice, corn, oil palm, pepper, cocoa, and rubber. Tropohemists soil types are suitable for lowland rice. From the analysis result, the soils are classified as having low fertility, except sulfaquents which have high fertility, but this type of soil is not suitable for agriculture development because it is tidal land which is only suitable for pond fisheries.

According to USDA soil classification that Eutropepts soil is classified as inseptisol while tropudults is classified ultisol soil. Hydraquents, sulfaquents, and troporthents are classified as entisol soil. Entisol soil was situated in lower place and saturated water, but it was potential for farm and marsh, tides or lowland farms (Puslittanak 2000: Prasetyo et al. 2001). Areas with $>15-40 \%$ of sloping are dystropepts, troporthens, and tropudults soil types which are not potential for agriculture cultivation due to its sensitivity of erosions. The V-shaped topography and steep slope with shallow cross section soil are sensitive to erosion and should be prioritized for conservation areas or watershed protection forest (Puslittanak 2000).
In Santan 2 watershed, the proportion of land suitable for agriculture is even lower than in Santan 1. Santan 2 watershed is dominated by $15-40 \%$ of sloping which accounts for $55 \%$ of total area while $27 \%$ of areas have $>40 \%$ of sloping. There are 6 types of soil in Santan 2 watershed including those classified as dystropepts, troporthents, and tropudults which are situated in hilly and slope to moderately steep. Areas with topography of flat to moderately sloping ( $<15 \%$ of sloping) are potential to be developed for agriculture plants. These areas consist of $18 \%$ of total watershed extent and have soil types of eutropepts, sulfaquents, tropohemists, and tropudults soils. Those soil types are classified as intseptisol and ultisol soils.

\section{Land availability and land needs}

The calculation of land availability was carried out based on the Regulation of Ministry of Environment No. 17 Year 2009 about guidelines for determining environmental carrying capacity in spatial planning and regional planning. Land availability and land needs for agricultural production in Santan 1 and Santan 2 watersheds are shown in Table 4.

The studied areas have various extent of land availability and land needs in which only Muara Kaman sub-district in Santan 1 watershed that has surplus lands while South Sangatta, Teluk Pandan, South Bontang and Marangkayu have deficit lands. The highest land needs are in South Bontang as the sub-district has large number of inhabitants but small land availability. Teluk Pandan has 5,685 ha of land needs while the land availability is only 1,247 ha despite expanding the extent of land is still plausible. South Sangatta sub-district has 7,954 ha of land needs and 2,286 ha of land availability while Muara Kaman sub-district has 7,190 ha of land needs and 8,225 ha of land availability.

Table 3. The extent of area (in hectares) of Santan 1 and Santan 2 watersheds in East Kalimantan, Indonesia based on soil type classified across slope and topography

\begin{tabular}{|c|c|c|c|c|c|}
\hline \multirow[b]{2}{*}{ Type of soil } & \multicolumn{4}{|c|}{ Slope dan topography } & \multirow[b]{2}{*}{ Total } \\
\hline & $\begin{array}{l}<2 \% \\
\text { (Flat) }\end{array}$ & $\begin{array}{c}>2-15 \% \\
\text { (Moderately sloping) }\end{array}$ & $\begin{array}{c}>15-40 \% \\
\text { (Sloping and hilly) }\end{array}$ & $\begin{array}{c}>40 \% \\
\text { (Moderately steep) }\end{array}$ & \\
\hline \multicolumn{6}{|c|}{ Santan 1 Watershed } \\
\hline Dystropepts & & 0.00 & $43,546.97$ & $5,085.31$ & $48,632.28$ \\
\hline Eutropepts & 0.00 & $13,551.63$ & 0.00 & & $13,551.64$ \\
\hline Hydraquents & 446.69 & & & & 446.69 \\
\hline Rendolls & & & 193.62 & & 193.62 \\
\hline Sulfaquents & 88.40 & & & & 88.40 \\
\hline Tropohemists & $8,315.34$ & & & & $8,315.34$ \\
\hline Troporthents & & & $5,548.90$ & $4,319.32$ & $9,868.22$ \\
\hline Tropudults & & $3,099.26$ & $14,612.56$ & $29,673.78$ & $47,385.61$ \\
\hline Total & $8,850.43$ & $16,650.90$ & $63,902.05$ & $39,078.40$ & $128,481.78$ \\
\hline Proportion & $7 \%$ & $13 \%$ & $50 \%$ & $30 \%$ & \\
\hline \multicolumn{6}{|c|}{ Santan 2 Watershed } \\
\hline Dystropepts & & & $11,827.53$ & & $11,827.53$ \\
\hline Eutropepts & & $2,386.42$ & & & $2,386.42$ \\
\hline Sulfaquents & 332.66 & & & & 332.66 \\
\hline Tropohemists & $1,877.56$ & & & & $1,877.56$ \\
\hline Troporthents & & & $2,465.30$ & & $2,465.30$ \\
\hline Tropudults & & 20.21 & & $6,999.42$ & $7,019.63$ \\
\hline Total & $2,210.22$ & $2,406.63$ & $14,292.83$ & $6,999.42$ & $25,909.09$ \\
\hline Proportion & $9 \%$ & $9 \%$ & $55 \%$ & $27 \%$ & \\
\hline Total & $11,060.64$ & $19,057.53$ & $78,194.88$ & $46,077.82$ & $154,390.88$ \\
\hline
\end{tabular}


Table 4. Land availability and land needs for agricultural production in Santan 1 and Santan 2 watersheds in East Kalimantan, Indonesia

\begin{tabular}{|c|c|c|c|c|c|c|c|}
\hline \multirow{2}{*}{ Watershed } & \multicolumn{2}{|r|}{ Area } & \multirow{2}{*}{$\begin{array}{l}\text { Number of } \\
\text { inhabitants }\end{array}$} & \multirow{2}{*}{$\frac{\text { SL }}{(\mathbf{H a})}$} & \multirow{2}{*}{$\frac{\text { DL }}{\text { (Ha) }}$} & \multirow{2}{*}{$\begin{array}{l}\text { Carrying } \\
\text { capacity }\end{array}$} & \multirow{2}{*}{$\begin{array}{l}\text { Extent of } \\
\text { deficit (ha) }\end{array}$} \\
\hline & Sub-district & District & & & & & \\
\hline \multirow{5}{*}{ Santan 1} & South Sangatta & East Kutai & 22,731 & 2,286 & 7,954 & Deficit & 5,668 \\
\hline & Teluk Pandan & East Kutai & 15,253 & 1,247 & 5,685 & Deficit & 4,438 \\
\hline & Muara Kaman & Kutai Kartanegara & 20,385 & 8,225 & 7,190 & Surplus & 1,035 \\
\hline & South Bontang & Bontang City & 71,748 & 518 & 26,583 & Deficit & 26,065 \\
\hline & Marangkayu & Kutai Kartanegara & 18.278 & 2,846 & 4,014 & Deficit & 1,168 \\
\hline Santan 2 & Marangkayu & Kutai Kartanegara & 13.278 & 3,931 & 5,543 & Deficit & 36,304 \\
\hline
\end{tabular}

Note: SL: Land Availability (Ha), DL: Total Land Needs Equal to Rice (kg)

Table 5. The result of land capability analysis and land use suitability evaluation in Santan 1 watershed in East Kalimantan, Indonesia (BAPLAN 2015)

\begin{tabular}{|c|c|c|c|c|c|c|c|}
\hline \multirow{2}{*}{ Spatial plans } & \multicolumn{6}{|c|}{ Land capability class } & \multirow[b]{2}{*}{ Total (ha) } \\
\hline & II & III & IV & $\mathbf{V}$ & VI & VII & \\
\hline \multicolumn{8}{|l|}{ Cultivation area } \\
\hline Grove marsh & 70.41 & $1,612.69$ & & 104.54 & & & $1,787.64$ \\
\hline Secondary dryland forest & 137.50 & & $7,956.74$ & & 174.32 & $10,549.27$ & $18,817.83$ \\
\hline Secondary mangrove forest & & & 9.59 & 22.53 & & & 32.12 \\
\hline Secondary swamp forest & & 73.99 & & & & & 73.99 \\
\hline Timber plantation & $9,638.46$ & 739.36 & $31,596.39$ & & 403.36 & $4,362.87$ & $46,740.44$ \\
\hline Settlement & & 1.21 & & 1.84 & & & 3.05 \\
\hline Plantation & & & 6.30 & & & 31.09 & 37.39 \\
\hline Mining & 258.81 & 2.30 & $4,602.69$ & & 4.43 & $4,652.45$ & $9,520.68$ \\
\hline Dryland agriculture & 51.76 & 119.25 & 247.69 & & & 18.52 & 437.22 \\
\hline Mixed dryland agriculture & $1,352.21$ & 673.39 & 713.54 & & 0.24 & 56.99 & $2,796.37$ \\
\hline Marsh & 5.20 & 145.66 & & & & & 150.86 \\
\hline Farm & 24.75 & 441.52 & & & & & 466.27 \\
\hline Scrub and Bushes & $2,426.16$ & $3,247.82$ & $7,315.32$ & & 1.60 & $3,333.09$ & $16,323.99$ \\
\hline Fishpond & 2.84 & 184.48 & 64.41 & 313.72 & & & 565.45 \\
\hline Open ground & 238.52 & 618.67 & 378.98 & 4.08 & & 5.47 & $1,245.72$ \\
\hline Sub-total & $14,206.62$ & $7,860.34$ & $52,891.65$ & 446.71 & 583.95 & $23,009.75$ & $98,999.02$ \\
\hline \multicolumn{8}{|l|}{ Protected area } \\
\hline Grove marsh & 9.18 & 103.27 & 13.06 & & & 12.42 & 137.93 \\
\hline Secondary dryland forest & 750.22 & & $6,427.07$ & & $3,615.30$ & $10,092.08$ & $20,884.67$ \\
\hline Timber plantation & 14.68 & & & & 1.21 & 26.29 & 42.18 \\
\hline Mining & & & & & 217.44 & $1,223.42$ & $1,440.86$ \\
\hline Mixed dryland agriculture & 77.70 & 47.62 & 96.64 & & 149.97 & $1,468.94$ & $1,840.87$ \\
\hline Scrub and Bushes & $1,534.67$ & 302.32 & 746.49 & & $1,233.73$ & 599.73 & $4,416.94$ \\
\hline Open ground & 5.13 & & 16.45 & & & 9.86 & 31.44 \\
\hline Sub-total & $2,391.58$ & 453.21 & $7,299.71$ & - & $5,217.65$ & $13,432.74$ & 28,794.89 \\
\hline \multicolumn{8}{|l|}{12 miles of sea } \\
\hline Scrub and bushes & & 1.07 & & & & & 1.07 \\
\hline Fishpond & & 0.71 & & & & & 0.71 \\
\hline Sub-total & & 1.78 & & & & & 1.78 \\
\hline Total (ha) & $16,598.20$ & $8,315.33$ & $60,384.98$ & 446.71 & $5,801.60$ & $36,442.49$ & $127,989.31$ \\
\hline Percentage & $13 \%$ & $6 \%$ & $47 \%$ & $0,3 \%$ & $5 \%$ & $28 \%$ & \\
\hline
\end{tabular}

\section{Lands potential for agricultural development in Santan 1 watershed}

The results of land capability analysis based on limiting factors of soil textures, slope, drainage, erosion state, effective depth, and flood danger, there are 7 land capability classes in Santan 1 watershed and 4 land capability classes in Santan 2 watershed. Land capability classifications of both watersheds are shown in Table 5.

Land capability class in Santan 1 watershed area is dominated by class IV (47\%) can be used for annual crops and general agricultural plant but terrace technique is needed for soil conservation. Comino et al. (2019) confirm that the imminent transformation from sloping vineyards into terraced fields could lead several land degradation processes if poor management is carried out, and no control measures are applied during the process, such as the conservation of stone walls or vegetation cover above the embankment. 
While class II and III which are land with capability suitable for plants cultivation consist of $19 \%$ of total area; class V was only $0.03 \%$; while class VI and VII which are only suitable for Watershed Protection Forest and grassland were about $33 \%$. On class VI, the lands are not suitable for mining or being left as open ground as it has hydrological functions, however, there is 247.7 ha of dryland agriculture and 810.2 ha of mixed dryland agriculture (agroforestry). This land class possesses a high risk if used for cultivation of annual crops which need more careful management and intensive maintenance. On land underclass $\mathrm{V}$ which is located on flat topography and always flooded, but there is 1.8 ha of for human settlement.

Abdel Rahman et al. (2016) confirm Among them, the first four classes of land are used for agriculture or cultivation of crops. The classes from V to VIII are not capable of supporting cultivation of crops. They are for growing grasses, forestry, and supporting wildlife.

On land underclass VI, there are dryland agriculture and mining which are not compatible with land capability as characterized by moderate steep slope and shallow soil which have high risk of erosion. It needed to be managed well to avoid erosions by making well-built chair terrace. Similarly, on lands underclass VII consist of incompatible land uses in the form of coal mining $(5,556.3 \mathrm{ha})$, dryland agriculture (18.5 ha), mixed dryland agriculture (1,633.9 ha) and open ground (15.3 ha).

\section{Lands potential for agricultural development in Santan 2 watershed}

Based on spatial planning of Santan 2 watershed (Table 6 ), there are cultivation areas with land cover of swamp bushes, secondary mangrove forest, mining, scrub, and open ground. In the determination of spatial plans in Santan 2 watershed, they were determined incorrectly with the land capability class. There is 6,999.46 ha of lands underclass VII characterized by slope and high risk of erosion, yet there are used for timber plantation, oil palm, mining, dryland agriculture, mixed dryland agriculture, scrub and bushes, and open ground. In addition, lands underclass VII which are allocated for grassland and Production Forest but being used for oil palm, dryland agriculture, and mixed dryland agriculture.

Mining and open ground are not suitable for land under the class of II, III and IV. Dryland agriculture is located under the class VI where it could be used as cultivation areas although it may need intensive management. On lands underclass VII, there is oil palm on areas with $>40 \%$ of which is susceptible to erosion and landslide risk. The high slope is not recommended for agricultural crops, being left as grassland or being used as Production Forest.

The dominant land uses in Santan 2 watershed in 2015 are scrubs and bushes, timber plantation, and oil palm. Spatial Plans, determine the size for cultivation area is 25,905.49 ha, in which, in reality, there is still found some areas that are not used properly, such as for swamp bushes, secondary mangrove forest, and open ground. Areas with suitable land capability classes for agricultural cultivation are class II and III with combined proportion of $16 \%$ of total extent and class IV with $56 \%$. Areas not suitable for agricultural cultivation is class VII, covering $27 \%$ $(6,999.42$ ha) of total extent. However, there is inconsistency in class VII with the limiting factor of slope and erosion risk. There are lands incompatible for cultivation including timber plantation, plantation, dryland agriculture, and mixed dryland agriculture. Ramadhan et al. (2016) claimed that land situated on $>40 \%$ of slope are vulnerable to erosion and landslide. Yi et al., (2010) who did research in Enshi, China declared that human activities in using land for dryland agricultural cultivation and farms play important role in accelerating soil weathering which resulted in slope instability. The denser is the forest coverage proportion, the lower is the land affected by rain surface runoff.

Table 6. The result of land capability analysis and land use suitability evaluation in Santan 2 watershed in East Kalimantan, Indonesia (BAPLAN 2015)

\begin{tabular}{|c|c|c|c|c|c|}
\hline \multirow{2}{*}{ Spatial Plans } & \multicolumn{4}{|c|}{ Land Capability Class } & \multirow{2}{*}{ Total (ha) } \\
\hline & II & III & IV & VII & \\
\hline \multicolumn{6}{|l|}{ Cultivation areas } \\
\hline Grove marsh & 128.04 & 307.05 & 10.54 & & 445.63 \\
\hline Secondary mangrove forest & 26.20 & 147.54 & 37.35 & & 211.09 \\
\hline Plants forest & 20.21 & & $4,660.42$ & 660.21 & $5,340.84$ \\
\hline Plantation & 4.09 & & $2,891.29$ & $1,323.02$ & $4,218.40$ \\
\hline Mining & 6.04 & & 175.31 & 304.17 & 485.52 \\
\hline Dryland agriculture & & & 106.53 & 67.93 & 174.46 \\
\hline Mixed dryland agriculture & 898.34 & 117.85 & 723.28 & 42.20 & $1,781.67$ \\
\hline Scrub and Bushes & $1,155.72$ & 484.37 & $5,415.45$ & $4,477.38$ & $11,532.92$ \\
\hline Fishpond & 70.24 & 761.15 & 4.50 & & 835.89 \\
\hline Open ground & 97.73 & 56.17 & 600.62 & 124.55 & 879.07 \\
\hline Sub-total & $2,406.61$ & $1,874.13$ & $14,625.29$ & $6,999.46$ & $25,905.49$ \\
\hline \multicolumn{6}{|l|}{12 miles of sea } \\
\hline Secondary mangrove forest & & 3.34 & 0.17 & & 3.51 \\
\hline Fishpond & & 0.08 & & & 0.08 \\
\hline Sub-total & & 3.42 & 0.17 & & 3.59 \\
\hline Total (ha) & $2,406.61$ & $1,877.55$ & $14,625.46$ & $6,999.46$ & $25,909.08$ \\
\hline Percentage & $9 \%$ & $7 \%$ & $56 \%$ & $27 \%$ & $100 \%$ \\
\hline
\end{tabular}



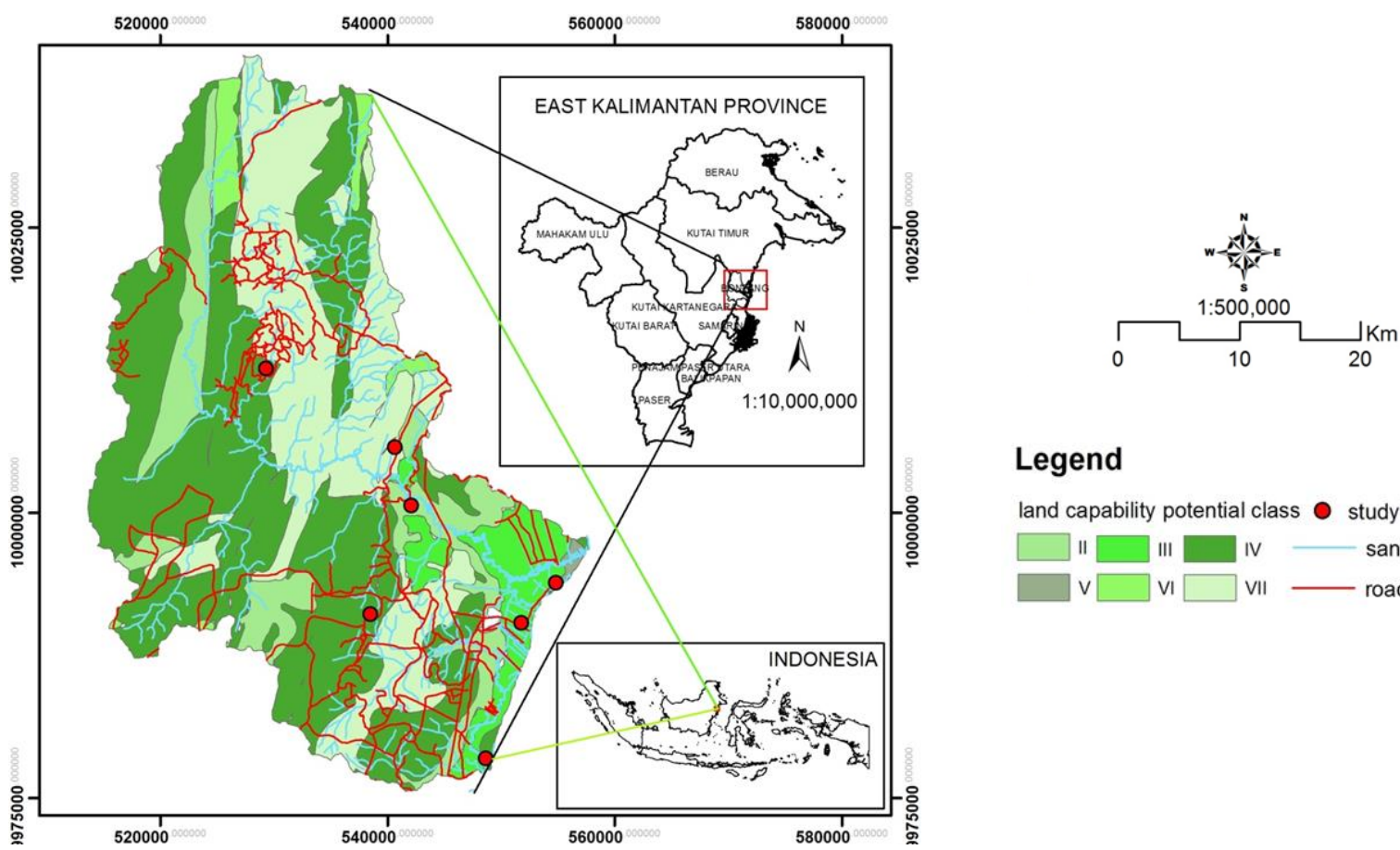

\section{Legend}

land capability potential class $\bigcirc$ study locatior

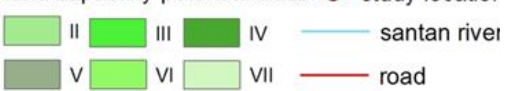

Figure 3. Land capability class of Santan 1 and Santan 2 watersheds in East Kalimantan, Indonesia

In conclusion, in Santan 1 and Santan 2 watersheds, areas with eutropepts and tropudults soils are potential to be developed for dryland agriculture while the tropohemist soil is suitable for the rice field development. Land availability in Santan 1 and Santan 2 watersheds is insufficient to fulfill land needs for agricultural development, resulting in land deficit since the populations are no match to land availability. The spatial plans in Santan 1 and Santan 2 watersheds are unsuitable with land capability where the cultivation areas are located in Class VI and VII with limiting factor of slope and risk of erosion. Scrubs and bushes are potential lands to be developed for dryland agriculture. In designing spatial plans for agricultural development areas, it is imperative to account for land capability.

\section{ACKNOWLEDGEMENTS}

Gratitudes are expressed to Indonesian Directorate General of Higher Education for funding this research through Post-Graduate Scholarship Program for Budget Year of 2012. We thank the Government of East Kutai District, Kutai Kertanegara District and Watershed Management Office (BPDAS) of East Kalimantan, Indonesia which granted research permission and provided information needed for this study. Thanks to Dr.Erwin, Dr.Harmonis, Arbain, Rinda Fitriani, Yosua Nabaho for discussion and suggestion.

\section{REFERENCES}

Abdel Rahman MAE, Natarajan A, Hegde R. 2016. Assessment of land suitability and capability by integrating remote sensing and GIS for agriculture in Chamarajanagar district, Karnataka, India. Egyptian J Rem Sens Space Sci 19: 125-141.

Arsyad S. 2010. Konservasi Tanah dan Air. Edisi Kedua. IPB Press, Bogor. [Indonesian]

Bani SN, Perwitasari, Farajallah D, Atmoko SSU, Sihite J. 2018. Adaptation behavior of Bornean Orangutan (Pongo pygmaeus moreo) reintroduction in KehjeSewen Forest, East Kalimantan, Indonesia. Biodiversitas 19: 989-996.

BAPLAN. 2015. Peta Penutupan Lahan Wilayah Propinsi Kalimantan Timur Dengan Klasifikasi Dan Nilai Skornya. Departemen Kehutanan RI, Jakarta. . [Indonesian]

Bhandari S, Santosh T. Jhadav2, Kumar S. 2014. Land capability classification and crop suitability assessment in a watershed using Rs and Gis - A case study of watershed in Dehradun. Uttarakhand Sci Soc Adv Res Soc Change 1: 1-15.

BPDAS Mahakam Berau. 2014. Laporan Hasil Penyusunan Klasifikasi DAS di Wilayah Kerja BPDAS Mahakam Berau. DITJEN Bina Pengelolaan DAS dan Perhutanan Sosial Kementerian Kehutanan, Samarinda. . [Indonesian]

Budiharta, S., Meijaard, E., Wells, J.A., Abram, N.K, Wilson, K.A. (2016) Enhancing feasibility: Incorporating a socio-ecological systems framework into restoration planning. Environ Sci Pol 64: 83-92.

Comino JR, Seeger M, Iserloh T, Gonzales MS, Sinoga DMR, Ries JB. 2019. Rainfall-simulated quantification of initial soil erosion processes in sloping and poorly maintained terraced vineyards - Key issues for sustainable management systems. Sci Total Environ 660: 1047-1057.

Costa RCA, Pereira GT, Pissarra TCT, Siqueira DS, Fernandes LFS, Vasconcelos V, Fernandes LA, Pacheco FAL. 2019. Land capability of multiple-landform watersheds with environmental land use conflicts. Land Use Pol 81: 689-704.

Fauzi RGN, Utomo DH, Taryana D. 2018. Pengaruh perubahan penggunaan lahan terhadap debit puncak di sub DAS Penggung Kabupaten Jember. Jurnal Pendidikan Geografi 1: 50-61. . [Indonesian] 
Hardjowigeno S, Widiatmaka. 2011. Evaluasi Kesesuaian Lahan dan Perencanaan Tataguna Lahan. Cetakan Kedua. Gadjah Mada University Press, Yogyakarta. [Indonesian]

Harjianto M, Sinukaban N, Tarigan, S.D, Haridjaja O.,2016. Land Capability Evaluation for Land Use Recommendation in Lawo Watershed Jurnal Penelitian Kehutanan Wallacea 5: 1-11. [Indonesian]

Maryati. 2013. Land Capability Evaluation of Reclamation Area in Indonesia Coal Mining Using LCLP Software. Procedia Earth Planet Sci 6: 465-473

Ministry of Environment. 2009. Concerning guidelines in spatial planning number 17 year 2009. [Indonesian]

Muhlisi, Gunawan W. 2016. Natural regeneration of mangrove seedlings in degraded area of Kutai National Park. Jurnal Penelitian Kehutanan Wallacea 5: 113-122. [Indonesian]

Prasetyo BH, Suping S, Subagyo H, Mujiono, Suhardjo H. 2001 Characteristics of rice soils from the tidal Flat areas of Musi Banyuasin, South Sumatra. Indonesian J Agric Sci 2: 10-26.

Puslittanak. 2000. Sumber Daya Lahan Indonesia dan Pengelolaannya. Badan Penelitian dan Pengembangan Pertanian, Departemen Pertanian, Bogor. . [Indonesian]

Rachman S, Muslim D, Sulaksana N, Burhannuddinnur M, Pramudito H. 2018. Analysis of slope stabillity and controlling factor on residual soil of folded breccia formation. IOP Conf Ser Earth Environ Sci 106 (2018) 012002 doi :10.1088/1755-1315/106/1/012002
Ramadhan R, Widiatmaka, Sudadi U. 2016. Land use change and spatial utilization in landslide vulnerable regions of Banjarnegara Regency, Central Java. Jurnal Pengelolaan Sumberdaya Alam dan Lingkungan $6: 159-167$. [Indonesian]

Rider R. 2003. Local soil knowledge and site suitability evaluation in the Dominican Republic. Geoderma 111: 289-305.

Roșca S, Bilaşco S, Păcurar I, Oncu M, Negruşier C, Petrea D. 2015. Land Capability Classification for Crop and Fruit Product Assessment Using GIS Technology. Case Study: The Niraj River Basin (Transylvania Depression, Romania). Not Bot Horti Agrobo 43: 235242.

Sawitri R, Suharti S, Karlina E. 2011. Community interaction with forest and their environment in Kutai National Park and its Buffer zone. Jurnal Penelitian Hutan dan Konservasi Alam 8: 129-142. [Indonesian]

Wangke H. 2017. The Management of Kutai National Park Through the Multi-Stakeholder Partnership. Adv Soc Sci Educat Human Res 167: 331.

Widiatmaka, Ambarwulan W, Paulus B.K. Santoso, Supiandi S, Machfud, Hikmat M. 2015. Remote sensing and land suitability analysis to establish local specific inputs for paddy fields in Subang, West Java. Procedia Environ Sci 33: 94-107.

Yi J, Yu B, Chen J, Huang J, Jing G. 2010. Analysis of landslides susceptibility to different land use patterns in Enshi, 2nd Conference on Environmental Science and Information Application Technology, IEEE, Wuhan, China 17-18 July 2010. 